Received: 22 May 2018

Accepted: 7 August 2018

Published online: 23 August 2018

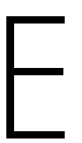

C N

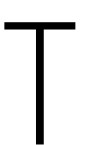

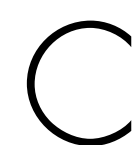

REP

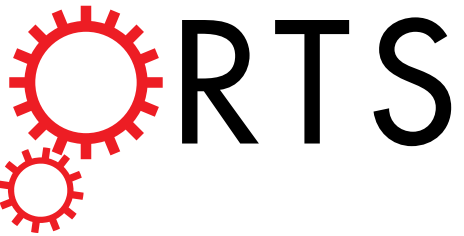

\title{
OPEN Thermal Stability of Hole-Selective Tungsten Oxide: In Situ Transmission Electron Microscopy Study
}

Haider Ali ${ }^{1,2}$, Supriya Koul ${ }^{1}$, Geoffrey Gregory ${ }^{1,2}$, James Bullock $\mathbb{D}^{3}$, Ali Javey ${ }^{3}$, Akihiro Kushima ${ }^{1}$ \& Kristopher O. Davis $\mathbb{1}^{1,2}$

In this study, the thermal stability of a contact structure featuring hole-selective tungsten oxide $\left(\mathrm{WO}_{\mathrm{x}}\right)$ and aluminum deposited onto $p$-type crystalline silicon (c-Si/WO$/ \mathrm{Al}$ ) was investigated using a combination of transmission line measurements (TLM) and in situ transmission electron microscopy (TEM) studies. The TEM images provide insight into why the charge carrier transport and recombination characteristics change as a function of temperature, particularly as the samples are annealed at temperatures above $500^{\circ} \mathrm{C}$. In the as-deposited state, $\mathrm{a} \approx 2 \mathrm{~nm}$ silicon oxide $\left(\mathrm{SiO}_{\mathrm{x}}\right)$ interlayer forms at the $\mathrm{c}-\mathrm{Si} / \mathrm{WO}_{\mathrm{x}}$ interface and $\mathrm{a} \approx 2-3 \mathrm{~nm}$ aluminum oxide $\left(\mathrm{AlO}_{\mathrm{x}}\right)$ interlayer at the $\mathrm{WO}_{\mathrm{x}} / \mathrm{Al}$ interface. When annealing above $500^{\circ} \mathrm{C}$, Al diffusion begins, and above $600^{\circ} \mathrm{C}$ complete intermixing of the $\mathrm{SiO}_{x,} \mathrm{WO}_{\mathrm{x}}$ $\mathrm{AlO}_{\mathrm{x}}$ and $\mathrm{Al}$ layers occurs. This results in a large drop in the contact resistivity, but is the likely reason surface recombination increases at these high temperatures, since a c-Si/Al contact is basically being formed. This work provides some fundamental insight that can help in the development of $\mathrm{WO}_{\mathrm{x}}$ films as hole-selective rear contacts for $p$-type solar cells. Furthermore, this study demonstrates that in situ TEM can provide valuable information about thermal stability of transition metal oxides functioning as carrier-selective contacts in silicon solar cells.

To achieve high conversion efficiencies ( $>25 \%$ ) for a single junction crystalline silicon (c-Si) solar cell, it is essential to couple low recombination velocities in the bulk and at the Si surface with suitable carrier selectivity at both electron and hole contact regions. These objectives can be achieved by inserting carrier selective contacts at both the front and rear surfaces of a silicon heterojunction cell. They help in passivating the Si surface by reducing surface recombination and they are carrier-selective in nature, meaning that they allow only one type of carrier, i.e., either of electron or holes to pass through it while blocking the other ${ }^{1-6}$.

Traditionally, carrier selective contacts have been realized using doped hydrogenated amorphous silicon (a-Si:H), wherein a-Si:H( $n)$ and a-Si:H( $p)$ act as electron-selective and hole-selective contacts respectively. These contacts are typically used in combination with a thin a-Si:H( $i)$ or $\mathrm{SiO}_{2}$ passivation layer. However, such cells suffer from certain inherent drawbacks associated with a-Si:H such as thermal instability, parasitic photon absorption, complicated deposition processes and high fabrication costs ${ }^{1,7-11}$.

Transition metal oxides have emerged as promising alternatives to doped a-Si:H for use as carrier selective contacts in silicon heterojunction cells. Depending on the valence-band and conduction-band offset between the metal oxide and $\mathrm{Si}$, transition metal oxides can be employed as either an electron-selective or a hole-selective contact. For instance, titanium oxide $\left(\mathrm{TiO}_{2}\right)$ has a small conduction band offset $\left(\Delta E_{\mathrm{c}}=0.05 \mathrm{eV}\right)$, which provides a low barrier for electrons to pass through the $\mathrm{TiO}_{2}$ layer and a large valence-band offset $\left(\Delta E_{\mathrm{v}}=2.0 \mathrm{eV}\right)$ that results in holes being blocked. Due to this reason, $\mathrm{TiO}_{2}(<5 \mathrm{~nm})$ has been employed as an electron-selective rear contact for an $n$-type cell with very promising results ${ }^{1,7,8,12,13}$.

On the other hand, if metal oxides have a wide band gap and high work function, the strong work function difference between $\mathrm{Si}$ and metal oxide induces a strong upward band bending in the c-Si which results in electrons being blocked. Because of this reason, sub-stochiometric metal oxides such as molybdenum oxide $\left(\mathrm{MoO}_{\mathrm{x}}\right)$ and tungsten oxide $\left(\mathrm{WO}_{\mathrm{x}}\right)$ have emerged as promising candidates for use as hole-selective contacts. Because of their wide band gap $(>3 \mathrm{eV})$ and consequently their high transparency, these materials have been employed as

${ }^{1}$ Department of Materials Science and Engineering, University of Central Florida, Orlando, FL, USA. ${ }^{2}$ Florida Solar Energy Center, University of Central Florida, Cocoa, FL, USA. ${ }^{3}$ Department of Electrical Engineering and Computer Science, University of California, Berkeley, CA, USA. Correspondence and requests for materials should be addressed to K.O.D. (email: Kristopher.Davis@ucf.edu) 
a)

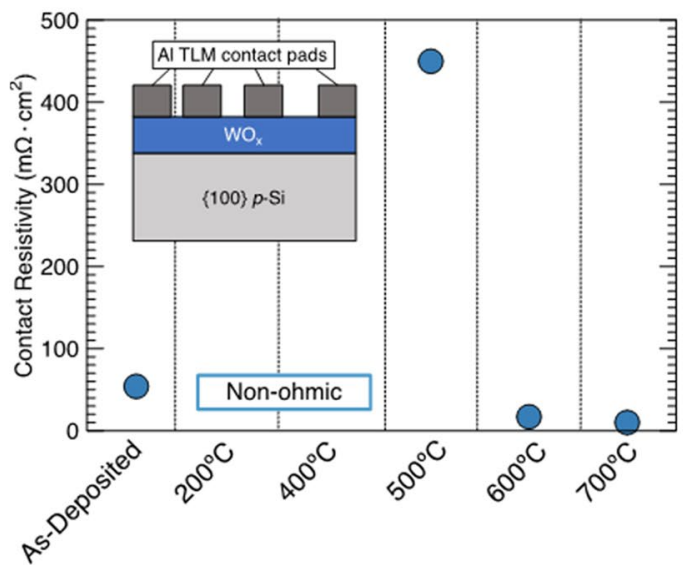

b)

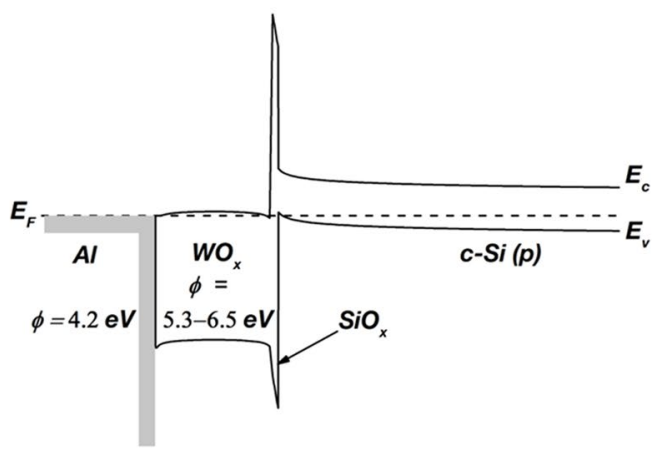

Figure 1. (a) Contact resistivity at various annealing temperatures obtained by TLM and (b) the energy band diagram of the $\mathrm{WO}_{\mathrm{x}} / \mathrm{Al}$ contact to $p$-type c-Si.

hole-selective front contacts in combination with a transparent conducting oxide (TCO) layer such as hydrogenated indium oxide (IO:H) or indium tin oxide (ITO $)^{2,14-18}$. However, a major limitation of these contact structures is that they are sensitive to low temperature annealing resulting in degradation of device performance. Although, the origin of these losses is yet to be fully understood, it is likely due to a reduction in the work function driven by hydrogenation and/or a lower oxygen concentration resulting in non-ideal hole-selectivity ${ }^{16,19}$.

Although, wide band gap and high work function transition metal oxides s (e.g., $\mathrm{MoO}_{\mathrm{x}}, \mathrm{WO}_{\mathrm{x}}$ ) in combination with TCO (e.g., IO:H, ITO) have been widely investigated as hole-selective front contacts for $n$-type solar cells; their application as potential hole-selective rear contacts are yet to be fully explored. Recently, Lee et al. demonstrated that $\mathrm{WO}_{\mathrm{x}} / \mathrm{Al}$ can be a potential candidate to be employed as a full area hole-selective rear contact for a $p$-type $\mathrm{Si}$ solar cells ${ }^{20}$. In the present work, the thermal stability of a c-Si/ $\mathrm{WO}_{\mathrm{x}} / \mathrm{Al}$ contact structure was investigated while being subjected to annealing temperatures up to $700^{\circ} \mathrm{C}$ with the help of in situ transmission electron microscopy (TEM). The contact resistivity at various annealing temperatures was measured by transmission line measurements (TLM). The objective is to achieve an in-depth understanding of the mechanisms influencing the stability of $\mathrm{WO}_{\mathrm{x}} / \mathrm{Al}$ contacts when subjected to high temperature annealing at the microscopic scale.

The values of contact resistivity measured at various annealing temperatures are shown in Fig. 1(a) and the inset illustrates the schematic of TLM structures employed for contact resistivity measurements. A typical energy band diagram of $\mathrm{WO}_{\mathrm{x}} / \mathrm{Al}$ contact to p-type $\mathrm{c}-\mathrm{Si}$ is shown in Fig. 1(b $)^{21}$. In the as-deposited state, the electrical behavior of the contact is ohmic and a contact resistivity value of $54 \mathrm{~m} \Omega \cdot \mathrm{cm}^{2}$ was obtained. Moreover, it is evident from cross-sectional HRTEM micrographs shown in Fig. 2(a) that even in the as-deposited state, an $\mathrm{AlO}_{\mathrm{x}}$ interlayer is formed at the $\mathrm{WO}_{\mathrm{x}} / \mathrm{Al}$ interface. A similar behavior has been previously reported for $\mathrm{Al} / \mathrm{TiO}_{2}$ contacts as well ${ }^{1,8}$. Likewise, in the case of $\mathrm{WO}_{\mathrm{x}} / \mathrm{Al}$, because of the higher oxygen affinity of $\mathrm{Al}$ as compared to the oxygen affinity of $\mathrm{W}$, diffusion of oxygen is more likely to occur from $\mathrm{WO}_{\mathrm{x}}$ towards $\mathrm{Al}$ resulting in formation of $\mathrm{AlO}_{\mathrm{x}}$ interlayer. This can lead to the creation of defect states such as oxygen vacancies within the $\mathrm{WO}_{\mathrm{x}}$ layer. Moreover, $\mathrm{a} \approx 2 \mathrm{~nm} \mathrm{SiO}$ interlayer is also observed at the $\mathrm{c}-\mathrm{Si} / \mathrm{WO}_{\mathrm{x}}$ interface. This is consistent with observation made by Sachetto et al. It is obvious that the formation of $\mathrm{SiO}_{\mathrm{x}}$ interlayer occurs during deposition of $\mathrm{WO}_{\mathrm{x}}$ by thermal evaporation and can be explained by thermodynamic considerations ${ }^{22}$. An effective carrier lifetime $\left(\tau_{\text {eff }}\right)$ value of $53 \mu$ s at an injection level $(\Delta n)$ of $1 \cdot 10^{15} \mathrm{~cm}^{-3}$ has been reported for as-deposited $\mathrm{WO}_{\mathrm{x}} / \mathrm{Al}^{20}$. It can be concluded that, in the as-deposited state, although $\mathrm{S} \mathrm{SiO}_{\mathrm{x}}$ interlayer forms, this layer provides very little surface passivation, and likely has a reasonably high interface defect density. Additionally, both the work function and film conductivity are sufficiently high to form an ohmic contact with a reasonably low contact resistivity in the as-deposited state.

When the sample is annealed to $200^{\circ} \mathrm{C}$ no significant change is observed (Fig. 2(b) and video 2(b)). However, TLM results show that contact structure becomes non-ohmic. One possible explanation for the non-ohmic transport is a reduction in the work function upon annealing in ambient air resulting in the formation of a barrier to hole collection. Additionally, if oxygen is diffusing from $\mathrm{WO}_{\mathrm{x}}$ to the $\mathrm{SiO}_{\mathrm{x}}$ interlayer, the $\mathrm{SiO}_{\mathrm{x}}$ interlayer may become more insulating ${ }^{22}$. This, however, requires further investigation. With respect to surface passivation of the $\mathrm{c}-\mathrm{Si} / \mathrm{WO}_{\mathrm{x}} / \mathrm{Al}$ contact stack, it has been previously reported that $\tau_{\text {eff }}$ drops from $53 \mu$ so $16 \mu \mathrm{s}\left(\Delta n=1 \cdot 10^{15} \mathrm{~cm}^{-3}\right)$ when annealed at $200^{\circ} \mathrm{C}^{20}$.

When the annealing temperature is increased to $400^{\circ} \mathrm{C}$, no apparent structural change is observed in the contact stack and the electrical behavior remains non-ohmic (Fig. 2(c) and video 2(c)). However, previous work on $\mathrm{c}$-Si/ $\mathrm{WO}_{\mathrm{x}} / \mathrm{Al}$ reported that $\tau_{\text {eff }}$ actually increases upon annealing at $400^{\circ} \mathrm{C}$ based on photoluminescence images of asymmetrical test structure, although it is unclear whether this increase was due to improved passivation of the $\mathrm{SiO}_{\mathrm{x}}$ interlayer at the $\mathrm{WO}_{\mathrm{x}}$ (i.e., rear) side of the device, or due to an improvement in the surface passivation at the front side of the device ${ }^{20}$. Yang et al. have reported that in case of $\mathrm{SiO}_{2} / \mathrm{TiO}_{2} / \mathrm{Al}$ rear contacts, annealing at $350^{\circ} \mathrm{C}$ is essential to activate the surface passivation of $\mathrm{SiO}_{2}{ }^{7,8}$. Therefore, it is possible that when the annealing temperature is increased to $400^{\circ} \mathrm{C}$, it activates the passivation mechanism of $\mathrm{SiO}_{\mathrm{x}}$ which results in increase in $\tau_{\text {eff. }}$. 
(a)

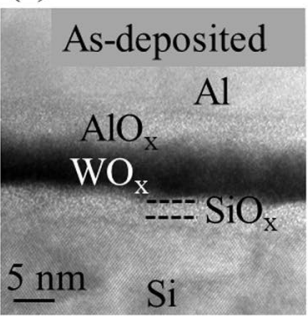

(e)

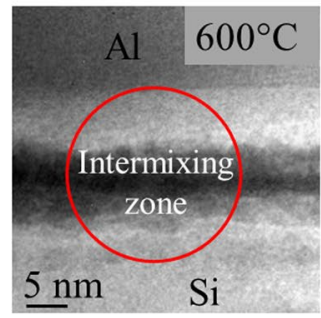

(b)

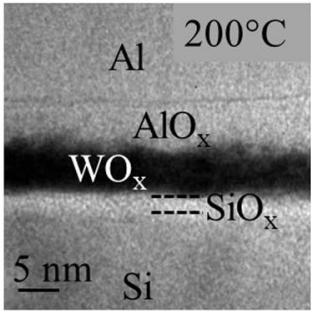

(f)

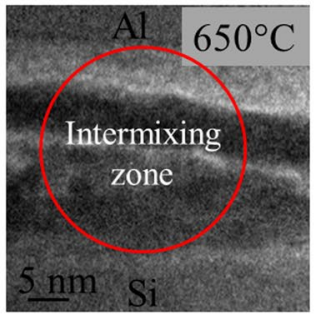

(c)

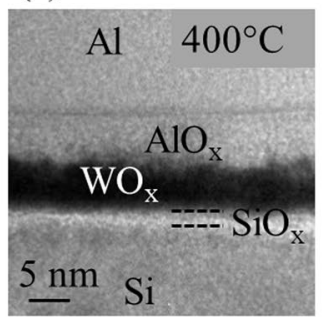

(g)

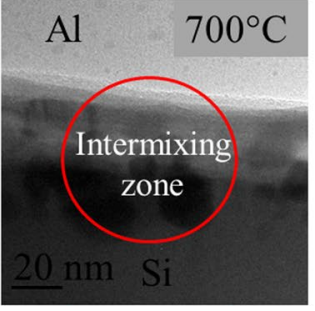

(d)

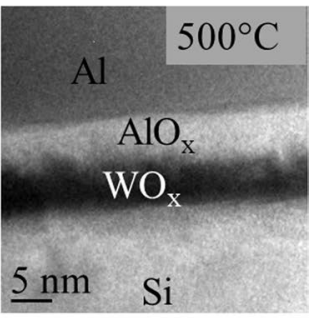

Figure 2. Cross-sectional HRTEM micrograph of c-Si/ $\mathrm{WO}_{\mathrm{x}} / \mathrm{Al}$ structure obtained by in situ TEM studies (a) as-deposited, (b) $200{ }^{\circ} \mathrm{C}$, (c) $400^{\circ} \mathrm{C}$, (d) $500^{\circ} \mathrm{C}$, (e) $600^{\circ} \mathrm{C}$, (f) $650^{\circ} \mathrm{C}$, (g) $700^{\circ} \mathrm{C}$.

When the annealing temperature is further increased to $500^{\circ} \mathrm{C}$, interfaces becomes diffused, indicating that significant phase changes may begin to occur at $500^{\circ} \mathrm{C}$ (Fig. $2(\mathrm{~d}$ ) and video 2 (d)). Furthermore, the TLM studies revealed that the behavior of the contact structure changes from non-ohmic to ohmic, although the contact resistivity value obtained was significantly higher at $450 \mathrm{~m} \Omega \cdot \mathrm{cm}^{2}$. It has been previously reported that crystallization of $\mathrm{WO}_{\mathrm{x}}$ occurs at $400^{\circ} \mathrm{C}^{20}$, although no evidence of crystallization was found during in situ TEM observation. It is likely that $\mathrm{WO}_{\mathrm{x}}$ begins to crystallize at $400^{\circ} \mathrm{C}$ and continues when further annealed to $500^{\circ} \mathrm{C}$. However, short annealing times $\left(\approx 10\right.$ minutes) are insufficient for the $\mathrm{WO}_{\mathrm{x}}$ to undergo complete crystallization, even at $500^{\circ} \mathrm{C}^{20}$. Therefore, ohmic behavior upon annealing to $500^{\circ} \mathrm{C}$ with a relatively higher contact resistivity can be attributed to partial crystallization of $\mathrm{WO}_{\mathrm{x}}$.

As already discussed, when annealing temperature is increased beyond $500{ }^{\circ} \mathrm{C}$, it is likely that the phase changes begins to occur in $\mathrm{WO}_{\mathrm{x}} / \mathrm{Al}$. Furthermore, at $600^{\circ} \mathrm{C}$, intermixing takes place between $\mathrm{SiO}_{\mathrm{x}}, \mathrm{WO}_{\mathrm{x}}, \mathrm{AlO}_{\mathrm{x}}$ and Al layers (Fig. 2(e) and video 2(e)). At $650^{\circ} \mathrm{C}$, the layers become indistinguishable (Fig. 2(f) and video 2(f)). At $700^{\circ} \mathrm{C}$, intermixing between $\mathrm{Si}, \mathrm{WO}_{\mathrm{x}}$ and $\mathrm{Al}$ appears to be near completion and $\mathrm{Al}$ is in direct contact with $\mathrm{Si}$ (Fig. 2(g)). This can be explained in terms of thermodynamic considerations. It is well known that the melting point of $\mathrm{Al}$ is $660^{\circ} \mathrm{C}$, and in the range of $100-150^{\circ} \mathrm{C}$ below the solvus line, $\mathrm{Al}$ begins to lose its integrity and diffusion begins. This explains why diffused interfaces were observed at a temperature of $500^{\circ} \mathrm{C}$. $\mathrm{Al}$ is the faster diffusing species than $\mathrm{W}$ because of the much smaller atomic radius. And as the annealing temperature is increased beyond $500^{\circ} \mathrm{C}, \mathrm{Al}$ atoms diffuse towards Si substrate with an exponentially increasing rate of diffusion with temperature. Eventually, at $650^{\circ} \mathrm{C}$, which is near the melting point of pure $\mathrm{Al}$, significant intermixing occurs. Finally, at $700^{\circ} \mathrm{C}$, the intermixing process nears completion and the Al layer comes in direct contact with the $\mathrm{Si}$. Therefore, much lower contact resistivity values of $17 \mathrm{~m} \Omega \cdot \mathrm{cm}^{2}$ and $10 \mathrm{~m} \Omega \cdot \mathrm{cm}^{2}$ were obtained at $600^{\circ} \mathrm{C}$ and $700^{\circ} \mathrm{C}$, respectively. This implies that drastic drop in contact resistivity upon annealing at $600^{\circ} \mathrm{C}$ and beyond is most likely due to direct contact between $\mathrm{Al}$ and $\mathrm{Si}$. However, this is an adverse effect on carrier selectivity and surface passivation, which is consistent with lower $\tau_{\text {eff }}$ values reported at $600{ }^{\circ} \mathrm{C}^{20}$, and basically negates the whole purpose of using $\mathrm{WO}_{\mathrm{x}}$.

Overall, it emerged that although $\mathrm{WO}_{\mathrm{x}} / \mathrm{Al}$ is a potential candidate to be employed as a hole-selective rear contact on a $p$-type cell, certain issues remain. To activate the passivation mechanism of $\mathrm{SiO}_{\mathrm{x}}$, annealing samples at $400^{\circ} \mathrm{C}$ may be sufficient, but $\mathrm{WO}_{\mathrm{x}} / \mathrm{Al}$ becomes non-ohmic at that temperature. This can possibly be overcome by annealing $\mathrm{WO}_{\mathrm{x}} / \mathrm{Al}$ for longer times to allow sufficient time for crystallization of $\mathrm{WO}_{\mathrm{x}}$, which can make it more conductive, but care must be taken to not reach the point of intermixing resulting in essentially a c-Si/Al contact.

In summary, some fundamental insight that can help in the development of $\mathrm{WO}_{\mathrm{x}}$ films as hole-selective rear contacts for p-type solar cells has been provided in this study. Furthermore, this work has successfully demonstrated that in situ TEM can provide valuable information about thermal stability of transition metal oxides employed as carrier-selective contacts in silicon solar cells.

\section{Experimental Section}

$\mathrm{WO}_{\mathrm{x}}$ thin films $(<10 \mathrm{~nm}$ ) were deposited on 5-10 $\Omega . \mathrm{cm}$ p-type FZ $\{100\} \mathrm{c}$-Si wafers under vacuum by thermal evaporation using a powder $\mathrm{WO}_{3}$ source. During the evaporation process, heating of the c-Si substrate was minimized and remained close to ambient temperature. This was followed by evaporation of $500 \mathrm{~nm}$ of $\mathrm{Al}$ to form the metal contact. For the contact resistivity measurements, TLM structures were fabricated, previously shown as an inset in Fig. 1(a). Dark I-V measurements were taken for the TLM contact pairs at different spacings using a Keithley 2400 Sourcemeter. This was done on samples exposed to different post-deposition annealing 
temperatures. This data was then used to extract the contact resistivity of the $\mathrm{WO}_{\mathrm{x}}$ contact stack, and the data was corrected for current spreading due to the absence of an emitter using the extended TLM ${ }^{23}$.

For TEM studies, cross-sectional TEM specimens were prepared by the focused ion beam (FIB) milling technique using FEI 200 TEM FIB. Specimen lift-out was done in situ and attached to $\mathrm{Cu}$ grid. To monitor morphological changes occurring at elevated temperatures, the sample was analyzed using TEM and was heated in situ. The in situ TEM experiments was performed using a Gatan heating holder (Model 652) in combination with a FEI Tecnai F30 under operating voltage of $300 \mathrm{kV}$. The samples were annealed in situ up to a temperature of $700^{\circ} \mathrm{C}$ with a heating rate of $50^{\circ} \mathrm{C} / \mathrm{min}$ and an annealing time for each temperature of $10 \mathrm{~min}$. However, a major limitation of using a Gatan heating holder (652) is that it is not compatible with energy dispersive $\mathrm{x}$-ray spectroscopy (EDX) systems. This is because the TEM specimen is surrounded by a furnace without any direct line of sight from the sample to the EDX detector due to which it is unable to detect characteristics X-rays essential for determination of chemical composition.

\section{References}

1. Ali, H., Yang, X., Weber, K., Schoenfeld, W. V. \& Davis, K. O. Transmission Electron Microscopy Studies of Electron-Selective Titanium Oxide Contacts in Silicon Solar Cells. Microscopy and Microanalysis 23, 900-904 (2017).

2. Bivour, M., Temmler, J., Steinkemper, H. \& Hermle, M. Molybdenum and tungsten oxide: High work function wide band gap contact materials for hole selective contacts of silicon solar cells. Solar Energy Materials and Solar Cells 142, 34-41 (2015).

3. Feldmann, F. et al. Carrier-selective contacts for Si solar cells. Applied Physics Letters 104, 181105, https://doi.org/10.1063/1.4875904 (2014).

4. Aberle, A. G. Surface Passivation of Crystalline Silicon Solar Cells: A Review. Progress in Photovoltaics: Research and Applications 8, 473-487 (2000)

5. Ali, H., Moldovan, A., Mack, S., Schoenfeld, W. V. \& Davis, K. O. Transmission electron microscopy based interface analysis of the origin of the variation in surface recombination of silicon for different surface preparation methods and passivation materials. physica status solidi (a), 1700286 (2017).

6. Ali, H. et al. Influence of surface preparation and cleaning on the passivation of boron diffused silicon surfaces for high efficiency photovoltaics. Thin Solid Films 636, 412-418, https://doi.org/10.1016/j.tsf.2017.06.043 (2017).

7. Yang, X., Zheng, P., Bi, Q. \& Weber, K. Silicon heterojunction solar cells with electron selective TiO $_{\mathrm{x}}$ contact. Solar Energy Materials and Solar Cells 150, 32-38 (2016).

8. Yang, X. et al. High-Performance $\mathrm{TiO}_{2}$-Based Electron-Selective Contacts for Crystalline Silicon Solar Cells. Advanced Materials 28, 5891-5897 (2016).

9. Bullock, J. et al. Amorphous silicon passivated contacts for diffused junction silicon solar cells. Journal of Applied Physics $\mathbf{1 1 5}$, 163703, https://doi.org/10.1063/1.4872262 (2014).

10. Bivour, M., Reichel, C., Hermle, M. \& Glunz, S. W. Improving the a-Si:H(p) rear emitter contact of n-type silicon solar cells. Solar Energy Materials and Solar Cells 106, 11-16 (2012).

11. Bullock, J. et al. Simple silicon solar cells featuring an a-Si:H enhanced rear MIS contact. Solar Energy Materials and Solar Cells 138, 22-25 (2015)

12. Yang, X. \& Weber, K. In Photovoltaic Specialist Conference (PVSC), IEEE 42nd. 1-4. (2015).

13. Allen, T. G. et al. A Low Resistance Calcium/Reduced Titania Passivated Contact for High Efficiency Crystalline Silicon Solar Cells. Advanced Energy Materials 7, 1602606 (2017).

14. Gerling, L. G. et al. Transition metal oxides as hole-selective contacts in silicon heterojunctions solar cells. Solar Energy Materials and Solar Cells 145, 109-115 (2016).

15. Bullock, J., Cuevas, A., Allen, T. \& Battaglia, C. Molybdenum oxide $\mathrm{MoO}_{\mathrm{x}}$ : A versatile hole contact for silicon solar cells. Applied Physics Letters 105, 232109, https://doi.org/10.1063/1.4903467 (2014).

16. Geissbühler, J. et al. $22.5 \%$ efficient silicon heterojunction solar cell with molybdenum oxide hole collector. Applied Physics Letters 107, 081601 (2015).

17. Battaglia, C. et al. Silicon heterojunction solar cell with passivated hole selective $\mathrm{MoO}_{\mathrm{x}}$ contact. Applied Physics Letters 104, 113902 (2014).

18. Gerling, L. G., Voz, C., Alcubilla, R. \& Puigdollers, J. Origin of passivation in hole-selective transition metal oxides for crystalline silicon heterojunction solar cells. Journal of Materials Research 32, 260-268 (2016).

19. Neusel, L., Bivour, M. \& Hermle, M. Selectivity issues of $\mathrm{MoO}_{\mathrm{x}}$ based hole contacts. Energy Procedia 124, 425-434, https://doi. org/10.1016/j.egypro.2017.09.268 (2017).

20. Lee, C.-Y., Aziz, M. I. A., Wenham, S. \& Hoex, B. Characterisation of thermal annealed $\mathrm{W}_{\mathrm{O}} \mathrm{x}$ on p-type silicon for hole-selective contacts. Japanese Journal of Applied Physics 56, 08 MA08 (2017).

21. Mews, M., Korte, L. \& Rech, B. Oxygen vacancies in tungsten oxide and their influence on tungsten oxide/silicon heterojunction solar cells. Solar Energy Materials and Solar Cells 158, 77-83, https://doi.org/10.1016/j.solmat.2016.05.042 (2016).

22. Sacchetto, D. et al. ITO/MoO $/ \mathrm{a}-\mathrm{Si}: \mathrm{H}(\mathrm{i})$ Hole-Selective Contacts for Silicon Heterojunction Solar Cells: Degradation Mechanisms and Cell Integration. IEEE Journal of Photovoltaics 7, 1584-1590 (2017).

23. Woelk, E. G., Krautle, H. \& Beneking, H. Measurement of low resistive ohmic contacts on semiconductors. IEEE Transactions on Electron Devices 33, 19-22 (1986).

\section{Acknowledgements}

This material is based upon work supported by the U.S. Department of Energy's Solar Energy Technologies Office under Award Number DE-EE0007533. Materials Characterization Facility (MCF) at University of Central Florida (UCF) is acknowledged for usage of its facilities. Materials characterization was also supported by the Electronic Materials Programs, funded by the Director, Office of Science, Office of Basic Energy Sciences, Material Sciences and Engineering Division of the U.S. Department of Energy under Contract No. DE-AC02-05CH11231.

\section{Author Contributions}

H.A.: experimental design, manuscript preparation, in situ TEM studies; S.K.: manuscript preparation, in situ TEM studies; G.G.: manuscript preparation, TLM studies; J.B.: manuscript preparation, fabrication; A.J.: experimental design, manuscript preparation; A.K.: experimental design, manuscript preparation; K.D.: experimental design, manuscript preparation. 


\section{Additional Information}

Supplementary information accompanies this paper at https://doi.org/10.1038/s41598-018-31053-w.

Competing Interests: The authors declare no competing interests.

Publisher's note: Springer Nature remains neutral with regard to jurisdictional claims in published maps and institutional affiliations.

(c) (1) Open Access This article is licensed under a Creative Commons Attribution 4.0 International License, which permits use, sharing, adaptation, distribution and reproduction in any medium or format, as long as you give appropriate credit to the original author(s) and the source, provide a link to the Creative Commons license, and indicate if changes were made. The images or other third party material in this article are included in the article's Creative Commons license, unless indicated otherwise in a credit line to the material. If material is not included in the article's Creative Commons license and your intended use is not permitted by statutory regulation or exceeds the permitted use, you will need to obtain permission directly from the copyright holder. To view a copy of this license, visit http://creativecommons.org/licenses/by/4.0/.

(C) The Author(s) 2018 